\title{
The Role Of Social Capital To Boost The Growth Of Smes In Tourism Sector In Bali
}

\author{
Putu Ngurah Suyatna Yasa \\ \{Info.warmadewa.ac.id\} \\ Master of Management Universitas Warmadewa Bali
}

\begin{abstract}
This study aims to determine the role of social capital in the forms of participation in the working, mutual trust, mutual giving (reciprocity), social norms, and values to negate the use of loan capital. Qualitative research design (post positivism) against 20 key informants using an interactive interpretive analysis shows that social capital in the form of participation in the net working, trust, resiprocity, social norms and values are very important role in reducing dependence on the use of loans. In the life of Balinese people, the implementation of social capital values is a culture of everyday life in all aspects of life, such as mutual cooperation culture, profit sharing institutions, various forms of local wisdom that all ethnic groups have, mutual reciprocity, trust each other, help each other, application of ethics and morals as well as values that originated from religious teachings. Social capital can actually be developed as part of modern economic culture. So far, social capital has been tested by history as an important mechanism, such as the mutual cooperation and family spirit in Bali that capable of becoming a medium of economic growth and equity in the application of Village Credit Institutions (LPD) empowerment, the establishment of various public and religious facilities, most of which pure selfhelp community in Bali. As conclusion, the role of social capital is very important. The main conclusions of this study are as follows: Social capital through the variables of participation in the networking, self-confidence/trust, mutual giving (reciprocity), social norms, and values are important variables in saving business capital in the SMEs in Gianyar Regency.
\end{abstract}

Keywords: social capital, venture capital, and SMEs of craft industry

\section{Introduction}

The existence of small and medium entreprises (SMEs) in Bali is absolutely necessary in the provision of various community needs, both for local communities and foreign tourists. Overall the number of SMEs in Bali shows a relatively high number, which is equal to more than $99 \%$. The type of small business that is growing rapidly in Bali is the handicraft industry (SMEs), as one of the key sectors of export commodities in addition to livestock, textiles, garments, and paper. SMEs contribution to Bali's Gross Regional Domestic Product (GRDP). Judging from the value of handicraft exports to Bali's total exports occupying the second largest number after apparel, which amounted about to $13,94 \%$ (BPS Bali, 2017). In the area 
of Bali it is famous for various SMEs with a unique and distinctive touch of art that is influenced by local wisdom inspired by Hinduism. It is this local wisdom that animates Balinese human artwork so that it has a distinctive difference from other regional works. The work of Balinese humans has been widely known throughout the world because it is supported by a Hindu-based culture that is reflected through various works of art, both dance, painting and engraving through various handicraft products. Culture is the result of relations between humans and nature, their births are motivated by religious norms, and local customs, the historical development, the system of livelihoods, social life, religion, knowledge, and a variety of arts become the background of local cultural life [1].

This study was conducted in Gianyar Regency, because Gianyar Regency has the largest number of SMEs compared to other districts in Bali, besides the analysis of the industrial sector location quotient (LQ) based on Bali investment supporting master plan data, indicating that Gianyar Regency has LQ values that the largest among other districts/cities in Bali for the industry service sector. This means that Gianyar Regency has the largest industrial development potential in the Province of Bali. The presence of SMEs in Gianyar Regency is able to absorb 30 percent of the workforce absorbed in the SMEs sector in Bali (Bali Cooperative and UMKM Office, 2017), and is widespread in six sub-districts, namely: Gianyar District, Blahbatuh, Ubud, Sukawati, Tegallalang and Tampaksiring. SMEs products are the main superior for Gianyar Regency which gave the second largest contribution to Gianyar's GRDP after the agricultural sector, which amounted to $18.06 \%$. The types of SMEs that developed in Gianyar Regency include: non-machine weaving, batSMEs, lace, Balinese dance clothing, palm weaving, wood carvings, iron crafts, bamboo handicrafts, gold/silver handicrafts, paintings, woven pandanus, painting eggs, and barong crafts.

In economic development planning in most countries in the world, including Indonesia, it always emphasizes aspects of natural capital and economic capital, such as man-made capital goods, technology and management, and ignores too many social capital roles, such as the existence of local institutions, local wisdom, local norms and culture. Conscious economic empowerment of the community is designed as part of community development, but in reality economic development is SMEs being released and not rooted in the community. As a result, on going economic empowerment feels alien to the community, and lacks benefits, ultimately showing economic dualism that creates social inequality as a trigger for massive poverty and unemployment and has continued continuously to the present since Indonesia's independence in 1945. In the life of Balinese people, the implementation of social capital values is a culture of everyday life in all aspects of life, such as mutual cooperation culture, profit sharing institutions, various forms of local wisdom that all ethnic groups have, mutual reciprocity, trust each other, help each other, application of ethics and morals as well as values that originate from religious teachings. Social capital can actually be developed as part of modern economic culture [2]. So far, social capital has been tested by history as an important mechanism, such as the mutual cooperation and family spirit in Bali capable of becoming a medium of economic growth and equity in the application of Village Credit Institutions (LPD) empowerment, the establishment of various public and religious facilities, most of which pure self-help community in Bali. Therefore, in the economic empowerment of people who are concerned, the role of social capital is very important.

This research is certainly inseparable from several studies that have been carried out, one of them is [3] who examines the role of social capital in the development of small and medium business networks, a case study at Padang restaurant. In his findings explained that high level of trust between individual can form strong social capital so they can form the social network in community, role of social capital in each individual affect capacity and quality of the 
community, social capital that used effectively can give motivation for business development, while social capital that was not used effectively can detain the opportunity in business development. In addition, there are also other related studies, [4] in research on the role of social capital in the development of cadger from Padang area at Sandratex Rempoa Ciputat explains that social capital plays a role in building agreed norms among cadgers. Still about the role of social capital, [5] also examined the same thing, it's just that the role of government and business performance was also examined in that study and it was found that social capital indirectly has a positive and significant effect on the subjective achievement. Referring to these results above, it is also very important to examine the role of social capital to boost the growth of SMEs in the tourism sector that has never been studied before. Thus, this study aims to determine the role of social capital in the form of participation in the networking, mutual trust, mutual giving (reciprocity), social norms, and values to negate the use of loan capital.

\section{Method}

This study uses a qualitative (post positivism) design. This research was conducted in Gianyar Regency, which is the district that has the largest number of small and medium enterprises (SMEs) among districts/cities in. Determination of informants is done by non probability sampling method, namely purposive sampling, this technique is suitable for qualitative research and does not make generalizations [6]. The number of informants was chosen by 20 people, including wood sculpture carvings, bamboo handicrafts, silver gold handicrafts, painting eggs, woven pandanus, barong crafts, and paintings. The selection of informants using the snowball technique. Data collection method are in-depth interviews, unstructured active observation, and triangulation. This study uses interpretive interaction analysis of collected data, then reduced / summarized, then presented, concluded and verified at the same time. The stages of analysis include the prior analysis in the field, analysis of data in the field and post-field analysis with analysis of cultural themes (discovering cultural themes) [6]. The interview process was carried out interactively and continued continuously to completion using the method of Miles and Huberman [6] such as Figure 1.

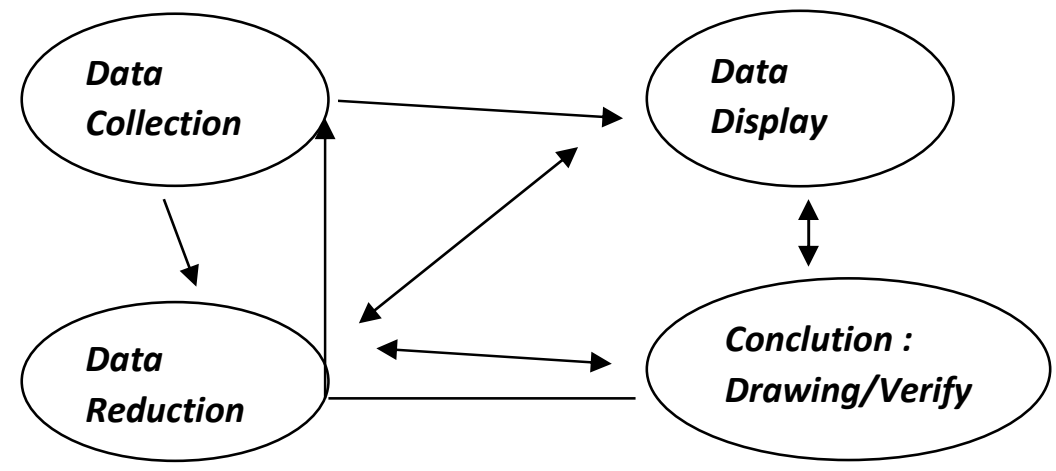

Fig.1 interactive model of component analysis 


\section{Result And Discussion}

\subsection{Variable participation in the networking}

In general, the SMEs production process in Gianyar Regency is based on orders, the ordering party always gives a down payment, the amount of which varies, depending on good relations and trust between them, which is between 15 and 50 percent. In general, they use the down payment to pay for all production activities, especially buying raw materials and other supporting needs. If the first ordering party has not taken or has not repaid the order, the need to pay the labor wage is taken from the next order down payment. They are never empty of orders, because the marketing varies, both domestically and export with certain ubscriptions.

It does not require relatively large capital in all production activities, because some production equipment is carried by workers. SMEs engaged in wood carving is the majority of 74.83 percent of all SMEs in Gianyar Regency (BPS Gianyar in 2017), the main capital for workers is the ability to carve and soften sourced from physical power, with the main equipment a set of carving equipment complete that can be used up to 10 years, the equipment is carried by the respective workers themselves, so the SMEs owner does not need to provide capital to purchase the carving equipment. Raw materials are given by the order or collector, the SMEs only works on the final process with labor capital only. In SMEs made from wood and lace, the processed raw materials are received in the form already ready to be carved, crooked or painted. The SMEs only does work called finishing, which is making carvings, lace, or painting according to the order of the order, therefore the need for business capital in the form of work equipment is relatively small. There are links between reciprocity, business owners and workers, or between business owners, all the difficulties they face are done by helping each other and giving sincerely. This condition is in accordance with the theory of social capital [7], and [8], that social capital comes from norms, social strength, trust, and reciprocity, and networking can improve coordination and business efficiency.

Partial business capital is given by foreigners invited to do business. For certain SMEs such as those which are made from wood from marine waste, some of the business capital comes from foreigners who motivate business establishment. The products produced are sold for the consumption of foreign tourists who live in Bali, as well as export orders also with the help of the Frenchman, besides the payment process for each product ordered during this time smoothly, therefore capital has never been a problem in carrying out its business. Raw materials can be obtained through barter, specifically for ostrich egg raw materials with a ratio of the value of raw materials with carved values is 1 compared to 6 . This condition is carried out by the owner of Egg Painting.

\subsection{Variables of confidence/trust}

The delay in paying labor costs or raw materials is not a problem, because all parties in this case the workers and the owners of raw materials really understand the condition. This is closely related to the strong role of social capital, so that work processes can be carried out efficiently.

\subsection{Mutuality (Reciprocity)}

Never had capital difficulties because the payment system was carried out by cargo directly when the goods were collected. In the area of Tegallalang, the transaction model between SMEs and the ordering party is done through cargo services in the local village, the 
cargo collects products every week from one SMEs to another SMEs, when goods are collected directly paid by cargo, so they never have financial difficulties in carry out its production activities.

Some business equipment is rented, especially in processing raw materials, so capital requirements are relatively small. Some of the SMEs are mainly made from wood, buying raw materials in the form of bar wood which must be processed into raw materials.

Raw materials are delivered directly by suppliers so there is no need to buy transportation equipment. Most SMEs in searching for raw materials are delivered directly by raw material suppliers, the order process is only carried out by telephone, therefore the money needed to purchase capital goods in the form of vehicles is also unnecessary.

The output price is friendly, so it's always fast selling and the capital turnover is smooth. This means that the selling price of SMEs products can be bargained by buyers, for the important SMEs, the goods sell even though fortunately thin is not a problem. Therefore their financial needs continue to run smoothly, but it is difficult to experience relatively high growth.

\subsection{Social norms}

Afraid of the risk of not being able to pay installments and interest when looking for loan capital from outside. SMEs entrepreneurs in Gianyar regency generally have a business spirit that is still simple, they realize that the nature of production is uncertain, sometimes crowded sometimes lonely, generally they have the fear of looking for loans from outside. They realize that external loans (credit) and interest must be paid regularly every month, while their income is uncertain. Aware of the low managerial ability, unable to manage loan capital from outside. This condition is very closely related to the level of education of entrepreneurs, from 95 respondents it turns out elementary school graduates amounted to 16.84 percent, junior high school 15.79 percent, and high school 53.68 percent or 86.31 percent of respondents with high school education down, only 13.69 percent of respondents have Diploma and S1 education backgrounds. This means that the respondent's education level is related to managerial skills and decision making in business.

Has no guarantee when looking for credit from a financial institution. In general, their difficulties in looking for loans from outside is not guaranteed as a condition for borrowing loans from financial institutions. Bureaucracy in seeking financial institution loans is complicated. A common problem complained by SMEs entrepreneurs is that the bureaucracy is very complicated in finding credit loans from financial institutions, they generally have a very simple and unhappy mindset with something complicated and complicated.

\subsection{Values}

The motive for trying is simplicity and always grateful for what Ida Sang Hyang Widhi has given, the principle is the total surrender to Ida Sang Hyang Widhi Waca, what he has now is his destiny, therefore trying to do enough, the important thing is to continue even though small. 


\section{Conclusions}

The main conclusions of this study that the reasons for the SMEs entrepreneurs to eliminate loan capital are because they have social capital inherited from their ancestors, in principle they implement the principles of social capital including indicators of net working, trust, reciprocity, norms, and values, so that the production process becomes efficient because it does not require loan capital. Besides that, social capital through the variables of participation in the networking, self-confidence/trust, mutual giving (reciprocity), social norms, and values are important variables in saving business capital in the SMEs in Gianyar Regency.

\section{References}

[1] Glebet, Meganada, Y. Negara, Suwirya, and Surata, Traditional Regional Architecture of Bali. Denpasar: Bali Tourism Development Agency, 2002.

[2] J. Mawardi, "The Role of Social Capital in Community Empowerment," unity J. 32. Pmd., 2010.

[3] F. Azhari and M. K. Mawardi, "Peran Modal Sosial dalam Pengembangan Jaringan Usaha Kecil Menengah: Studi Kasus pada Rumah Makan Padang,” J. Adm. Bisnis, vol. 59, no. 1, 2018.

[4] B. H. Utomo, "Peran Modal Sosial terhadap Perkembangan Pedagang Kaki Lima Asal Daerah Padang di Sandratex Rempoa Ciputat," Universitas Islam Negeri Syarif Hidayatullah Jakarta, 2015 .

[5] G. . Gandhiadi, K. Dharmawan, and I. P. Kencana, "Peran Pemerintah, Modal Sosial, dan Kinerja Usaha terhadap Kesejahteraan Subjektif Pelaku Industri Tenun di Kabupaten Jembrana Bali," J. Mat., vol. 8, no. 1, 2018.

[6] Sugiyono, Quantitative, Qualitative, and $R \& D$. Research Methods. Bandung: Alfabeta, 2010.

[7] M. Porter, The Competitive Adventage of Nation. New York: Free Press, 1990.

[8] R. Putnam, Making democracy works. Princeton NJ: Princeton University Press, 1993. 